\title{
Introduction: cultural icons and cultural leadership
}

\section{Peter Iver Kaufman}

The editors have asked colleagues whether persons they study should be considered iconic because they represented cultural trends, because they challenged and changed their cultures' preoccupations and perceptions, or because they continue to influence or challenge our preoccupations and perceptions. Their answers, recorded in the following chapters, refine the concepts of iconicity and celebrity, probe the meaning of "cultural leadership," and - in many papers - contemplate the significance of personal crises as well as the character and influence of politics and pieties around their subjects. The contributions appear in this book chronologicallyfrom early modern to postmodern - but it seemed wise to deploy brief introductions to the chapters topically, in the context of some reflections on recent directions in cultural studies and leadership studies.

Depositing some form of the word "culture" twice in a title may well be reckless. Morris Dickstein called the term "slippery"; Clifford Geertz, whose influence on conversations about culture has been immense, deplored the "studied vagueness" with which the term "culture" was nearly always invoked. Yet he was undeterred and held that "culture" could - and should - be used to signify patterns of meanings "embodied in symbols." For Geertz, "system[s] of inherited conceptions expressed in symbolic forms" are ways people satisfy their curiosity as well as ways that "communicate, perpetuate, and develop their knowledge about and attitudes toward life." Y Yet Geertz seems to have raised one of the questions that enliven and enrich studies presented here. Predictably, mention of historical transmission and inherited conceptions stirs scholars to sift subcultures, small units embedded in or orbiting around any dominant pattern of meaning. But the leadership of iconic figures - their upbringings and their uprisings - is often overlooked when one explores hegemonic cultures as well as the protests they prompted.

Stephanie Paulsell visits with Virginia Woolf's grandparents, parents and other kin to illustrate how sectarian evangelicalism, agnosticism, abolitionism and spiritualism tilted what has been called Woolf's and feminism's 
"prototypical narratives." 2 Yaakov Ariel turns to Allen Ginsberg's family culture to discover some of the resources that reinforced the poet's resolve to assume artistic and spiritual leadership of what has come to be known as a "counter culture" that then set the trajectory of Ginsberg's experiments in literature and life. Evyatar Marienberg brings us to gritty Newcastle's working class culture experiencing hard economic times, from the 1950s into the 1970s. He takes us from shipyards into parochial schools, emphasizing the discipline that was characteristic of Catholic culture. Gordon Sumner, now known as Sting, emerged from those contexts or sub-cultures to set a pattern for performers whose barbed social commentary earned them fame as "Sting-like rebels."

Family and class cultures (or structures) fascinate us, as do fissures in encompassing cultures. The tempestuous relationship between the North and South in the United States, for example, was evident before the civil war of the nineteenth century, and, on Clark Gilpin's watch, both war and the uneasy peace that followed impelled Emily Dickinson to revive the genre of self-interrogation. She refashioned the ideals of intimacy, personal fulfillment and repentance while reflecting on memory, mourning and immortality. Gilpin's study calls to mind new historicists who urge historians to study the poetic and personal alongside the political. The new historicists helpfully explain to scholars interested in the arts and in cultural leadership why they may no longer rely on safeguards and protections of the category of the aesthetic to seal off their favorite texts, scores or artifacts from political contexts. Difficulties surface when, on some outings, historians presume to find a hegemonic culture's "drama of domination" (or the poetics of protest) in the fictions they sift. Keeping that caution in mind, however, one could argue that contributors to this volume probing cultural icons' political, spiritual and cultural challenges, expectations, disappointments and leadership offer tribute to the new historicism.

Yet contributors also address and contest many new historicists' temptations to minimize the importance of individual agency while identifying pervasive collective practices, constraints, institutions, representations and discourses. Elizabethan playwright Christopher Marlowe tends at times to be submerged in the history of his Queen's Counsels' anti-Catholic campaigns. He was, after all, recruited by Francis Walsingham, Elizabeth's principal secretary and, we would say today, head of counter-espionage to search for agents sent by the papacy and its Spanish and French allies to stage a coup in England. Yet, as co-editor Kristin Bezio explains in this volume, Marlowe's opposition to confessional conflict was comprehensive. His play Massacre at Paris was an excellent occasion to pour anti-Catholic propaganda into theaters, yet the script took aim at all partisans' propensity to violence. Bezio, moreover, proposes that Marlowe even dared to 
object to his Queen's and Walsingham's policy. Tracy Fessenden agrees that Billie Holiday's haunting versions of "God Bless the Child" are unforgettable but, Fessenden notices, easy to misconstrue. They deserve a prominent place along the course from spirituals to swing, as historians concede, describing that "course" as a welcome, critical part of the "success story of individual fortitude and freedom into which . . . African-American historical experience [is] more generally fitted." But Fessenden shows that "the singer and song bear witness to other legacies," "other powers." Holiday neither attested success nor celebrated self-possession; rather, Fessenden concludes, she defiantly announced her presence "amid the sites of injury we call racism, inequality, [and] addiction," "choos[ing] not to budge, not to move forward, but ... to let her spirit or genius linger in witness and testify." If, as some dictionaries assert, iconicity and leadership require admiration and success, Marlowe and Holiday are cultural icons whose status was awarded posthumously.

Allen Ginsberg achieved notoriety while alive, although he and his eccentricities were seldom, if ever, associated with cultural leadership until he was all but anointed a "prophet of postmodernism." As Yaakov Ariel confirms, Ginsberg's reputation for riddling performances grew as mainstream publishers as well as literary magazines took an interest in the Beat writers. Sir Walter Scott, knighted in 1820, a year after his Ivanhoe was published, was immediately and internationally acclaimed as a master of historical romance; still, his leadership and iconic status were even more firmly established, as Caroline McCracken-Flesher suggests, when he became "the figure around whom a culture assembled in an act of recognition and self-expression" and, subsequently, the centerpiece of Scottish civil religion.

Cultural icons have to be rather sturdy to weather the waves of criticism that celebrated figures ordinarily attract during their times and thereafter. Typically, they are afflicted by what Matthew Arnold called "an awful sense of the impossibility of being at ease in Zion." "3 Some seem to proceed from that sense or sensitivity to arraign complacency and to favor energetic, unconventional responses to predicaments similar to those Robert Boyers identified when he lamented that "the language of value and discrimination" has been "emptied of meaning." He specified that "what is said to be 'fresh' or 'original' is actually calculated"; "what is said to be outrageous and brash is actually audience-tested, obvious in its appeal and entirely safe." Any remedy, Boyers presumes, must be accompanied by a "spiritual militancy," which appears to be characteristic of nearly all the cultural icons included in this volume. What John Keats said about genius may also be said about them: they "live in gusto." 4 But to what end? How clear were their purposes to them? To their contemporaries? Contributors 
to this volume confront questions of this sort as well as others. Were (and are) cultural icons and leaders in constant quarrel with convention? Friendly critics? Did (or do) they abhor clichés yet become clichés?

Jennifer Airey discusses Mary Shelley's "discomfort with the masculine Romantic ethos," specifically, with Romanticism's optimistic take on the power of literature to reform "the moral world," which was something of a cliché even in her time. On that count, Shelley interrogated and came to distrust views held by her illustrious husband. He is best known for his Ozymandias and his friendship with Lord Byron; she, for her Frankenstein. But Airey introduces readers to Mary Shelley's novella Mathilda, "an angry dismissal of Romantic philosophy" and "a sharp rebuke to male moralists," which confounds early nineteenth-century expectations about gender. Joseph Wiesenfarth also turns to literature relatively unfamiliar to admirers of his prolific, iconic author, Jane Austen, celebrated for the irony that fills her mature fiction. Wiesenfarth is interested in the Austen juvenilia stocked with humorously roguish characters and with stories that spoofed many of the irrationalities undergirding the "obvious" and "entirely safe" expectations of her time. So Austen here emerges as an uninhibited iconoclastic icon, with an eye for pretense and a delight that derived from having the pretentious in her sights. Early on, then, Austen exhibited what Wiesenfarth calls "a world of raw emotions that her novels later bring under control."

Kathryn Lofton's Bob Dylan is also an iconoclast, but one who seems to delight in sabotaging his own iconic standing. He is amused to be taken seriously and to have his songs construed as sermons. Lofton opens her chapter on Dylan with the concession that it risks putting her among scholars whom her subject finds ridiculous and repulsive for trying to pin him down, to have him "open each and every door." Yet a sound wager is that - "changeling" and trickster-Dylan would admire how deftly Lofton prowls around his "cultural location." Lofton, moreover, does not shy away from perhaps the most "problematic," controversial and endlessly interpreted turn in Bob Dylan's career, namely, his conversion to evangelical Christianity, concluding that a "fall-on-his-knees" Dylan was part of the repertoire of a "spiritual-but-not-religious" lyricist "looking for new religious intrigue, a new opportunity to transfigure." Virginia Woolf's pieties, as Stephanie Paulsell documents, are just as intriguing. Woolf imagined that T.S. Eliot - a near neighbor in this volume-absurdly, contentedly, but ruefully (or "obscene[ly]") would sit by his fire content to believe in the God revealed by, yet concealed in the Christian religion. ${ }^{5}$ Woolf's restless search for intimations of the sublime took her "beneath ordinary existence" rather than into the heavens. Jane Austen, a clergyman's daughter, applauded King Henry VIII for having dissolved the 
monasteries, Joe Wiesenfarth reminds us, citing her juvenilia's assessment that their reduction to ruins was "of infinite use to the ... landscape." Sir Walter Scott seemed to have been indifferent to religion's institutional presence but looked quite unfavorably on what Caroline McCracken-Flesher characterizes - channeling Scott - as "the overdeterminations and entitlements of dogma." Allen Ginsberg, Yaakov Ariel reports, attempted to make "mainstream" religion wider, indefatigably experimenting with forms of spirituality that were unfamiliar in the West. And what of T.S. Eliot, his faith and his fire? What did he think of others' iconoclasm or secularism? Cyrena Pondrom catches him ill-at-ease with a convoy of critics who took his early poetry to express "the disillusionment of a generation." Eliot was almost certainly dismayed that traditional religions' engagements with the Enlightenment nearly always amounted to (or ended as) accommodations. ${ }^{6}$ His faith, to some, might have seemed — as it did to Virginia Woolf—like a donnish foible, but he thought that it was worth "abdicat[ing]" his position as poet of modernism, "reject[ing] modernism for medievalism," Pondrom explains, suggesting that, in the process, he traded iconicity for cultural leadership.

Contributors take different approaches to iconicity, leadership and piety, yet all seem to find in the personalities they present to us what Hannah Arendt found in Brecht and Auden, that is, an "immortalizing liveliness" that depended on creative artists' readiness to "operate on facts" and, at times, tell "the least welcome truths." 7 The contributions belong in a single album, if only because contributors, reflecting on cultural icons' cultural leadership, seem to agree that poetic invention makes an important difference, summoning change or resisting it, and because, as John Gardner's notoriously censorious, crabby survey of "moral fiction" concludes, "we live or die by the artists" vision[s], sane or cracked"; "the business of civilization is to pay attention." 8

\section{NOTES}

1. Clifford Geertz, The Interpretation of Cultures: Selected Essays (New York: Basic Books, 1973), 89. The essay, "Religion as a Cultural System," was originally published in 1965. For "slippery," see the preface to Dickstein's first edition of Gates of Eden: American Culture in the Sixties, reprint edition (New York: Norton, 2015), xxiv. That study of culture, published in 1977, conceded that competing "sensibilities" made it difficult to identify a single culture in the 1960s, yet Dickstein wrote as if his small sample of creative artists' work could yield "a tissue of assumptions" that would, in turn, enable him to repossess "the texture of feeling and opinion," which, he maintained, constituted "culture as a whole." Reviewers were quick to identify parts of "the cultural landscape" that Culture in the Sixties left untilled. For example, see Richard H. King, "A Conflict of Decades," Reviews in American History 6 (1978), 129-30. 
2. Jane Marcus, "Pathographies: The Virginia Woolf Soap Operas," Signs 18 (1992), 807.

3. Matthew Arnold, Culture and Anarchy (Cambridge: Cambridge University Press, 1954), $134-5$.

4. John Keats, Selected Letters of John Keats, revised edition, ed. Grant F. Scott (Cambridge: Harvard University Press, 2002), 194-5; Robert Boyers, "Pleasure Revisited," Raritan 30 (2010), 126-8.

5. Virginia Woolf, The Letters of Virginia Woolf: Volume Three, 1923-1928, ed. Nigel Nicolson and Joanne Trautmann (New York: Harcourt/Harvest, 1980), 457-8, quoted in Cyrena Pondrom's contribution, infra, Chapter 7, this volume.

6. David Hollinger, "The Accommodation of Protestant Christianity with the Enlightenment: An Old Drama still being Enacted," Daedalus 141 (2012), 77.

7. See Hannah Arendt, Reflections on Literature and Culture, ed. Susannah Young-ah Gottlieb (Stanford: Stanford University Press, 2007), 226-31, 294-302; Ian Storey, "The Reckless Unsaid: Arendt on Political Poetics," Critical Inquiry 41 (2015), 879.

8. John Gardner, On Moral Fiction (New York: Basic Books, 1978), 204-205. 